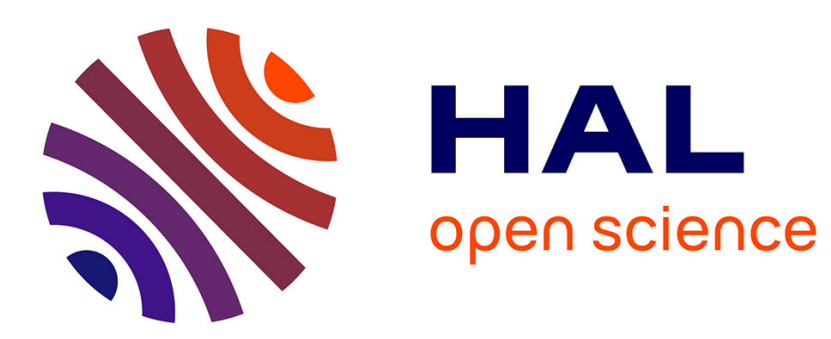

\title{
Hydroamination of ethylene with NH 3 induced by non-thermal atmospheric plasma
}

Julien Dieu, François Jérôme, Catherine Batiot-Dupeyrat

\section{To cite this version:}

Julien Dieu, François Jérôme, Catherine Batiot-Dupeyrat. Hydroamination of ethylene with NH 3 induced by non-thermal atmospheric plasma. Reaction Chemistry \& Engineering, 2021, 10.1039/D1RE00407G . hal-03421008

\section{HAL Id: hal-03421008 https://hal.science/hal-03421008}

Submitted on 9 Nov 2021

HAL is a multi-disciplinary open access archive for the deposit and dissemination of scientific research documents, whether they are published or not. The documents may come from teaching and research institutions in France or abroad, or from public or private research centers.
L'archive ouverte pluridisciplinaire HAL, est destinée au dépôt et à la diffusion de documents scientifiques de niveau recherche, publiés ou non, émanant des établissements d'enseignement et de recherche français ou étrangers, des laboratoires publics ou privés. 


\section{Hydroamination of ethylene with $\mathrm{NH}_{3}$ induced by non-thermal atmospheric plasma}

Received 00th January 20xx, Accepted 00th January 20xx

\author{
Julien Dieu, François Jérôme*, Catherine Batiot-Dupeyrat*
}

DOI: $10.1039 / \times 0 \times x 00000 x$

\begin{abstract}
We show here that non-thermal atmospheric plasma induces the cleavage of the $\mathrm{N}-\mathrm{H}$ bond of $\mathrm{NH}_{3}$ to form aminium radicals, which then add onto ethylene to form ethylamine in $17 \%$ yield. This technology can be also extended to n-octene, leading to the formation of 1-octylamine, i.e. with anti-Markovnikov addition of $\mathrm{NH}_{3}$.
\end{abstract}

Amines are ubiquitous molecules in our daily life, with a wide range of applications in the fields of agriculture, food, medicine, personal care, polymers, etc. ${ }^{1}$ In this context, the hydroamination of alkenes is a reaction of considerable interest, as it provides a hydrogen-free access to amines in a $100 \%$ atom economical fashion. So far, this reaction has been extensively explored in the presence of catalysts such as transition metals, bases and acids. ${ }^{2}$ However, to overcome thermodynamic limitations $(\Delta \mathrm{G} \sim 0 \mathrm{~kJ} / \mathrm{mol})^{, 3}$ activated alkenes (i.e. featuring ring strain, conjugation, or substitution with electron-withdrawing groups) and/or intramolecular hydroamination reactions were mainly investigated. ${ }^{2}$ The utilization of $\mathrm{NH}_{3}$, the simplest and the most abundant amine (160 million tons/year), ${ }^{4}$ in the hydroamination of alkenes is much more challenging but, so far, there is a lack of technology to successfully perform this reaction. ${ }^{5}$ Although it would open an access to primary alkyl amines from two cheap and abundant chemicals, utilization of $\mathrm{NH}_{3}$ in the hydroamination of non-activated alkenes remains a longstanding goal of catalysis. ${ }^{6}$ This reaction is indeed facing important scientific hurdles such as (i) the high $\mathrm{N}-\mathrm{H}$ bond dissociation energy of $\mathrm{NH}_{3}(415 \mathrm{~kJ} / \mathrm{mol}){ }^{7}$ (ii) the highest basicity of primary amines leading to a poisoning of the catalytic sites $^{2 a-e}$ and (iii) high activation energy barriers due to strong electrostatic repulsions of the nitrogen electron lone pair of $\mathrm{NH}_{3}$ with the electron-rich $\pi$ cloud of the alkene. ${ }^{8}$ Hence, high temperatures are often required to initiate this

IC2MP, ENSIP, Université de Poitiers, UMR CNRS 7285, 1 rue Marcel Doré, TSA 41105, 86073 Poitiers cedex 9, France E-mail : catherine.batiot.dupeyrat@univpoitiers.fr

tElectronic Supplementary Information (ESI) available: [details of any supplementary information available should be included here]. See DOI: $10.1039 / \mathrm{x} 0 \times x \times 0000 x$ catalytic reaction, which is unfortunately thermodynamically unfavorable.

In a pioneer study, Whitman reported that alkali metals, such as $\mathrm{Li}$ or $\mathrm{Na}$, catalyzed the hydroamination of ethylene with $\mathrm{NH}_{3}$ at $175-200^{\circ} \mathrm{C}$, but at a very high pressure (> 800 bar) to thermodynamically favor the reaction. ${ }^{9}$ Later, Deepa revisited this reaction in the presence of zeolites and reported a yield in ethylamine of $13 \% .{ }^{10}$ As demonstrated later by Bell, this low yield at the thermodynamic equilibrium was due to the high reaction temperature $\left(360^{\circ} \mathrm{C}\right)$ required to desorb ethylamine from the acid sites, thus inducing the uncontrolled Hoffman degradation of ethylamine back to $\mathrm{NH}_{3}$ and ethylene. ${ }^{11}$ Interestingly, Knowles showed that the formation of aminium radical cation, using Ir-based photocatalysts, was a promising strategy not only to favor the addition of alkyl amines on alkenes in an anti-Markovnikov fashion, but also to lower the activation energy barrier of the hydroamination reaction, resulting in a decrease of the temperature to $45^{\circ} \mathrm{C}^{12}$ In 2020, Yoshida applied this concept to $\mathrm{NH}_{3}$ and irradiated an aqueous $\mathrm{NH}_{3}$ solution in the presence of $\mathrm{TiO}_{2}$ photocatalysts and alkenes, affording primary amines in fair to good yields. ${ }^{13}$ Although water limits the applicability of this work (low solubility of alkenes, side oxidation of $\mathrm{NH}_{3}$ to $\mathrm{NO}_{\mathrm{x}}$ in water), it suggests that the radical pathway is a promising approach.

In this communication, we report preliminary results on a catalyst-free hydroamination of ethylene with $\mathrm{NH}_{3}$ induced by non-thermal atmospheric plasma. Our strategy was inspired by a previous study of Swiderek who pointed out the formation of ammonium radical cation at low temperature by exposing $\mathrm{NH}_{3}$ to a low-energy electron beam in an ultra-high vacuum chamber $\left(10^{-10}\right.$ Torr $) .^{14}$

In this study, a non-thermal atmospheric plasma (NTAP) was created in a dielectric barrier discharge (DBD) reactor consisting of an alumina cylinder and a central electrode. The NTAP volume was $1.2 \mathrm{~mL}$. More information on the DBD reactor can be found in the electronic supporting information (Fig. S1, S2). In such configuration, the electrons generated in the NTAP gas have mean energies in the range of 1 to $10 \mathrm{eV}^{15}$, and thus can induce the cleavage of gaseous molecules such as $\mathrm{CH}_{4}, \mathrm{O}_{2}, \mathrm{H}_{2}, \mathrm{NH}_{3}$, etc.... In a typical procedure, a mixture of 
ethylene and $\mathrm{NH}_{3}\left(\mathrm{C}_{2} \mathrm{H}_{4} / \mathrm{NH}_{3}\right.$ ratio of 0.5$)$ was first diluted in helium (70 vol\%) and then continuously introduced (50 $\mathrm{mL} / \mathrm{min}$ ) into the DBD reactor at room temperature and atmospheric pressure. Dilution of $\mathrm{C}_{2} \mathrm{H}_{4} / \mathrm{NH}_{3}$ in $\mathrm{He}$ was preferred in this work to facilitate the formation of the plasma gas but also to facilitate analysis of the reaction products by gas chromatography. The applied voltage and the frequency were first fixed at $12 \mathrm{kV}$ and $800 \mathrm{~Hz}$, respectively, so that the deposited power was $4 \mathrm{~W}$. At this low power, the average temperature of the DBD reactor does not exceed $50^{\circ} \mathrm{C}$ and, on the basis of previous reports, ${ }^{16}$ the decomposition of $\mathrm{NH}_{3}$ to $\mathrm{N}_{2}$ and $\mathrm{H}_{2}$ is expected to be limited at this power. The gas outlet of the DBD reactor was connected to a gas chromatography (GC) to determine online the conversion of ethylene and the yield of ethylamine. To our delight, under the above conditions, $30 \%$ ethylene was converted and the formation of ethylamine was detected by GC, with a yield of $10 \%$ (Fig. S3). Formation of ethylamine was further confirmed by mass spectrometry. The selectivity to ethylamine was $33 \%$ indicating the formation of other products, presumably stemming from the side polymerization of ethylene, as suggested by a slight deposit of black carbon on the electrode surface. To the best of our knowledge, this result constitutes one of the first examples of catalyst-free addition of $\mathrm{NH}_{3}$ to ethylene.

Next, the total flow rate $\left(\mathrm{C}_{2} \mathrm{H}_{4} / \mathrm{NH}_{3}=0.5\right.$ in helium) was varied from 50 to $100 \mathrm{~mL} \cdot \mathrm{min}^{-1}$ in order to determine the optimized residence time $(\tau)$ in the DBD reactor. $\tau$ is defined as the ratio between the volume of the reactor and the total flow rate. Results are presented in Fig. 1. The NTAP-induced hydroamination of ethylene with $\mathrm{NH}_{3}$ was a very fast reaction and occurred within $1 \mathrm{~s}$. Extending the residence time over $1 \mathrm{~s}$ did not result in a significant increase of both the ethylamine yield and the ethylene conversion, suggesting that the reaction was thermodynamically limited, as commonly observed with catalytic reactions (hydroamination vs Hoffman elimination). As a further evidence, the selectivity to ethylamine was found to be constant (30-33\%), whatever the conversion rate.

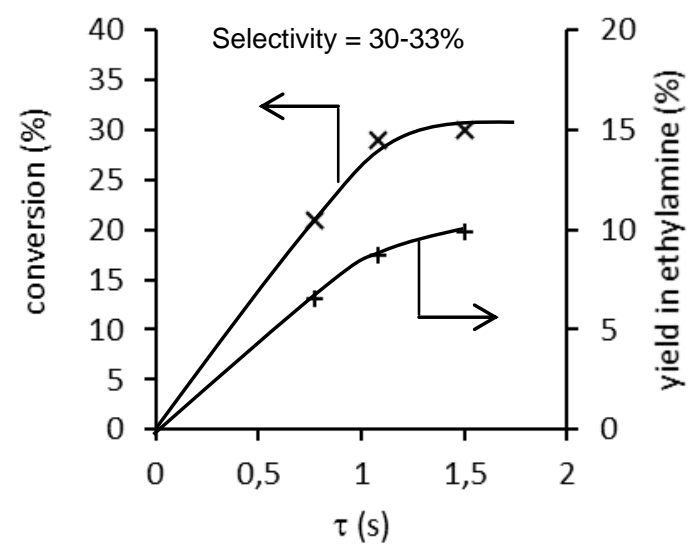

Figure 1 Influence of the residence time $(\tau)$ on the ethylene conversion and yield in ethylamine (total flow rate: $50,70,100 \mathrm{~mL}$. $\mathrm{min}^{-1}$, ratio $\mathrm{C}_{2} \mathrm{H}_{4} / \mathrm{NH}_{3}=0.5$, He: $70 \%, \mathrm{P}=4 \mathrm{~W}$ $(12 \mathrm{kV}, 800 \mathrm{~Hz}))$

The $\mathrm{C}_{2} \mathrm{H}_{4} / \mathrm{NH}_{3}$ ratio was then varied from 0.25 to 1 , while keeping unchanged the total flow rate of $\mathrm{C}_{2} \mathrm{H}_{4} / \mathrm{NH}_{3} / \mathrm{He}$ $\left(50 \mathrm{~mL} \cdot \mathrm{min}^{-1}\right)$ and the deposited power $(4 \mathrm{~W})$. Results are summarized in Figure 2. A steadily increase of the conversion of ethylene from $22 \%$ to $48 \%$ was observed when the $\mathrm{C}_{2} \mathrm{H}_{4} / \mathrm{NH}_{3}$ ratio was decreased from 1 to 0.25 . However, it did not result in a further increase of the ethylamine yield (10\%), suggesting the formation of a higher amount of side products at a $\mathrm{C}_{2} \mathrm{H}_{4} / \mathrm{NH}_{3}$ ratio of 0.25 . At this stage of our investigations, and with the analytical apparatus coupled online to our DBD reactor, it was difficult to determine with accuracy the nature of side products. From the literature, one may suspect the formation of di-/triethylamine and oligomers of ethylene. ${ }^{5}$ Hence, in the following experiments, the $\mathrm{C}_{2} \mathrm{H}_{4} / \mathrm{NH}_{3}$ ratio and the total $\mathrm{C}_{2} \mathrm{H}_{4} / \mathrm{NH}_{3} / \mathrm{He}$ flow rate were kept to 0.5 and 50 $\mathrm{mL} \cdot \mathrm{min}^{-1}$, respectively.

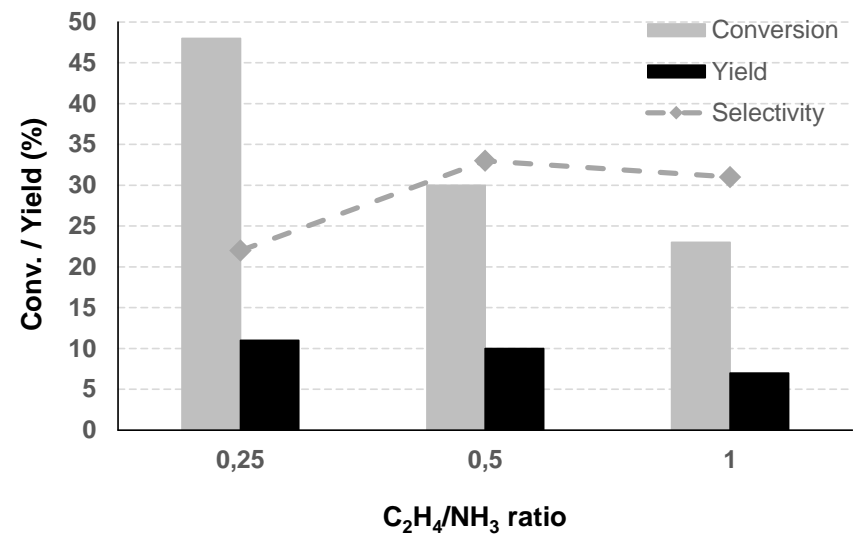

Figure 2 Influence of the ratio $\mathrm{C}_{2} \mathrm{H}_{4} / \mathrm{NH}_{3}(0.25,0.5,1)$, Total flow rate: $50 \mathrm{~mL}$. $\mathrm{min}^{-1}$, He: $70 \%, \mathrm{P}=4 \mathrm{~W}(12 \mathrm{kV}, 800 \mathrm{~Hz})$

The impact of the deposited power on the conversion of ethylene and yield in ethylamine was then assessed. It was observed that the conversion of ethylene was raised from 23 to $55 \%$ when the deposited power was concomitantly increased from 2 to $6 \mathrm{~W}$ (Fig. 3). This result might explained by the formation of a higher concentration of energetic electrons at a higher power input ${ }^{17}$ Interestingly, independently of the deposited powder, the selectivity to ethylamine remained constant (30\%). As a result, the yield in ethylamine was improved from $9 \%$ at $2 \mathrm{~W}$ to $17 \%$ at $6 \mathrm{~W}$. A higher deposited power was not explored due to the difficulty in this case to prevent $\mathrm{C}-\mathrm{C}$ and $\mathrm{C}-\mathrm{N}$ bond cleavage, as mentioned elsewhere. $^{18}$

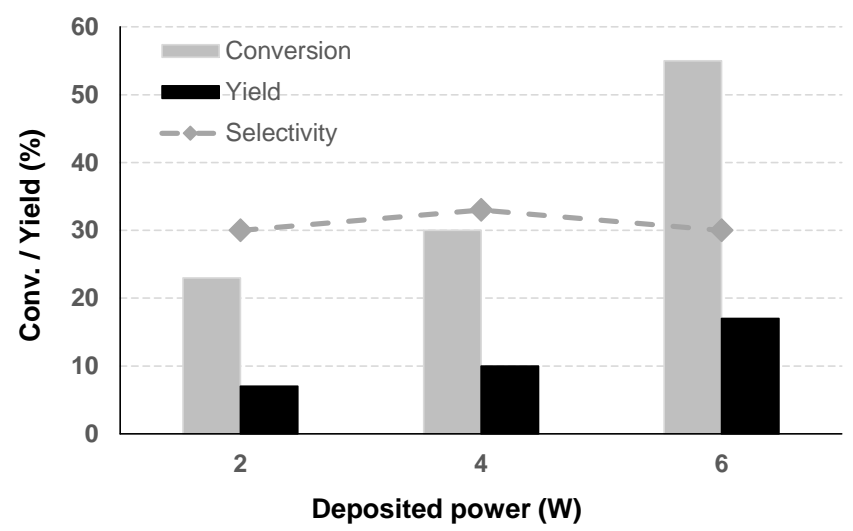

This journal is (C) The Royal Society of Chemistry 20xx 
Figure 3 Influence of the deposited power on the conversion of ethylene and yield in ethylamine (Total flow rate: $50 \mathrm{~mL} \cdot \mathrm{min}^{-1}$, Ratio $\mathrm{C}_{2} \mathrm{H}_{4} / \mathrm{NH}_{3}=0.5$, He: $70 \%$ ).

The plot of the ethylamine selectivity versus the ethylene conversion (measured at a deposited power of 2-6 W, Fig. 4) shows that the selectivity remained almost constant and close to $30 \%$, suggesting that (1) ethylamine is stable under our working conditions and thus (2) the formation of ethylamine and ethylene cracking/polymerization are two parallel reactions.

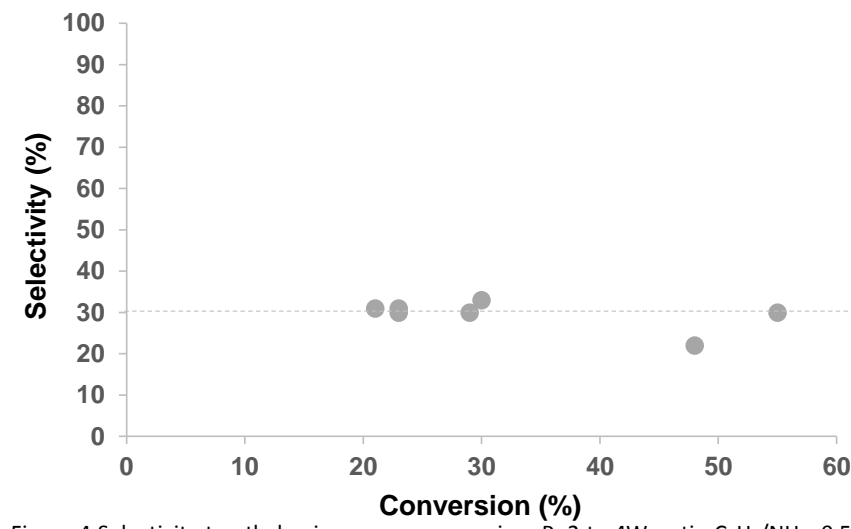

Figure 4 Selectivity to ethylamine versus conversion, $\mathrm{P}: 2$ to $4 \mathrm{~W}$, ratio $\mathrm{C}_{2} \mathrm{H}_{4} / \mathrm{NH}_{3}: 0.5-2$, Total flow rate: $50-100 \mathrm{~mL} \cdot \mathrm{min}^{-1}$

The ionization of ammonia $\left(\mathrm{NH}_{3}+\mathrm{e}^{-} \rightarrow \mathrm{NH}_{3}^{+\bullet}+2 \mathrm{e}^{-}\right)$and ethylene $\left(\mathrm{C}_{2} \mathrm{H}_{4}+\mathrm{e}^{-} \rightarrow \mathrm{C}_{2} \mathrm{H}_{4}^{+\bullet}+2 \mathrm{e}^{-}\right)$is 10.1 and $10.5 \mathrm{eV}^{19}$, respectively. Considering that the electrons energy generated within the NTAP gas is between $1-10 \mathrm{eV}^{15}$, it means that ionization of $\mathrm{NH}_{3}$ and ethylene is less likely occurs in our case. Hence, it suggests that the reaction proceeds through the formation of radicals through electron impact dissociation, as illustrated in a work of Lepoetre ${ }^{20}$ who evidenced the dissociation of $\mathrm{NH}_{3}$ into $\mathrm{NH}_{2}{ }^{\circ}$ and $\mathrm{H}^{\bullet}$ under plasma discharge To support this claim, ethylene was replaced by 1-octene (Fig. 5). Indeed, as previously evidenced by Knowles, ${ }^{12}$ addition of aminium radicals on alkenes occurs in an anti-Markovnikov fashion. In perfect agreement, when ethylene was replaced by 1-octene, formation of 1-octylamine was exclusively observed, supporting the occurrence of a radical mechanism (Fig. S4). It is noteworthy that this last result is of high interest, as acid, base and transition metal catalysts lead to a Markovnikov addition of the amine to the alkenes. The anti-Markovnikov addition of $\mathrm{NH}_{3}$ is not only scientifically more challenging, but also much more desirable due to the broader spectrum of applications of linear amines. ${ }^{5}$ At $4 \mathrm{~W}$, with a 1-octene/ $\mathrm{NH}_{3}$ ratio of 0.5 , the conversion of 1 -octene reached $78 \%$ with a yield in 1-octylamine of $14 \%$, showing in the meantime that this NTAP technology could be extended to other nonactivated alkenes.

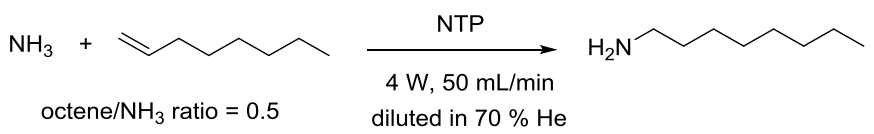

Figure 5. Anti-Markovnikov addition of $\mathrm{NH}_{3}$ to $n$-octene induced by NTAP
In conclusion, these preliminary results show that non-thermal atmospheric plasma could induce the hydroamination of nonactivated alkenes such as ethylene or $n$-octene with $\mathrm{NH}_{3}$. The originality of this study stems from the absence of catalysts, ammonia being activated by electron collision. Hence, the desorption (or decoordination) of primary amines from the catalytic sites is no more an issue. As a result, the pressure of $\mathrm{NH}_{3}$ was reduced to atmospheric pressure, while the average temperature of the reactor remained close to $50^{\circ} \mathrm{C}$.

Optimization of this reaction, in particular the use of more concentrated feeds of $\mathrm{NH}_{3}$ and $\mathrm{C}_{2} \mathrm{H}_{4}$, the structural determination of side products and the coupling of nonthermal atmospheric plasma with catalysis is now the topic of current investigations in order to better control the selectivity of involved radical reactions and also to improve the space time yield of this reaction. Optimization of the reactor geometry is also under investigations to improve the performances of this methodology in terms of energy consumption.

\section{Conflicts of interest}

There are no conflicts to declare.

\section{Acknowledgements}

The CNRS, University of Poitiers and the Région Nouvelle Aquitaine are strongly acknowledged for their financial support.

\section{Notes and references}

11 https://www.marketsandmarkets.com/MarketReports/alkylamines-market-726.html

22 a) J. I. Van der Vlugt Chem. Soc. Rev, 2010, 39, 2302-2322; b) T. E. Müller, K. C. Hultzsch, M. Yus, F. Foubelo, M. Tada, Chem. Rev., 2008, 108, 3795-3892; c) T. E. Müller, M. Beller, Chem. Rev., 1998, 98, 675-703; d) L. Huang, M. Arndt, K. Gooßen, H. H. Heydt, L. J. Gooßen, Chem. Rev. 2015, 115(7), 2596-2697; e) S. Hong and T. J. Marks Acc., Chem. Res., 2004, 37, 673-686; f) L. Legnani, B. N. Bhawal, B. Morandi Synthesis, 2016, 776-789; g) J. Seayad, A. Tillack, C. G. Hartung, M. Beller, Adv. Synth.Catal. 2002, 344, 795-813

33 a) Y. Li, T. J. Marks J. Am. Chem. Soc., 1996, 118, 92959306; b) J.-S. Ryu, G. Yanwu Li, T. J. Marks J. Am. Chem. Soc., 2003, 125, 12584-12605.

44 M. Kitano, Y. Inoue, Y. Yamazaki, F. Hayashi, S. Kanbara, S. Matsuishi, T. Yokoyama, S.-W. Kim, M. Hara, H. Hosono, Nat. Chem. 2012, 4, 934-940.

$5 \quad 5$ S. Streiff, F. Jérôme Chem. Soc. Rev., 2021, 50, 1512-1521.

$66 \mathrm{~J}$. Haggin Chem. Eng. News, 1993, 23-27.

77 a) J. J. Warren, T. A. Tronic, J. M. Mayer, Chem. Rev. 2010, 110, 6961-7001; b) J. Hoover, Science, 2016, 707-708.

88 E. Haak, S. Doye Chem. Unserer Zeit, 1999, 33, 296-303.

99 B. W. Howk, E. L. Little, S. L. Scott, G. M. Whitman, J. Am. Chem. Soc., 1954, 767, 1899-1902.

1010 a) M. Deeba, M. E. Ford and T. A. Johnson, J. Chem. Soc., Chem.Commun. 1987, 562-563; b) M. Deeba, M. E. Ford, Zeolites 1990, 10, 794-797.

1111 C. R. Ho, L. A. Bettinson, J. Choi, M. Head-Gordon, A. T. Bell ACS Catal. 2019, 9, 7012-7022. 
1212 a) A. J. Musacchio, B. C. Lainhart, X. Zhang, S. G. Naguib, T. C. Sherwood, R. R. Knowles, Science, 2017, 355, 727-730; b) D. C. Miller, J. M. Ganley, A. J. Musacchio, T. C. Sherwood, W. R. Ewing, R. R. Knowles, J. Am. Chem. Soc., 2019, 141 (42), 16590-16594.

1313 S. Park, J. Jeong, K.-I. Fujita, A. Yamamoto, H. Yoshida, J. Am. Chem. Soc., 2020, 142(29), 12708-12714.

1414 a) T. Hamann, E. Böhler, P. Swiderek, Angew. Chem., Int. Ed., 2009, 48, 4643-4645; b) E. Böhler, J. H. Bredehöft, P. Swiderek, J. Phys. Chem. C, 2014, 118, 6922-6933.

1515 B. Eliasson, U. Kogelschatz, IEEE Trans. Plasma Sci., 1991, 19, 1063-1077.

16 a) M. Akiyama, K. Aihara, T. Sawaguchi, M. Matsukata, M. Iwamoto, Int. J. Hydrogen Energy, 2018, 43 (31), 1449314497; b) Y. Zhao, L. Wang, J. Zhang, H. Guo, Int. J. Hydrogen Energy, 2014, 39 (15), 7655-7663; c) S. Lu, L. Chen, C. Du, X. Sun, X. Li,J. Yan, Int. J. Hydrogen Energy, 2014, 39 (35), 19990-19999.

1716 B. Eliasson, C. Liu, U. Kogelschatz Ind. Eng. Chem. Res., 2000, 39, 1221-1227.

1817 B. Eliasson, C. Liu, U. Kogelschatz, Ind. Eng. Chem. Res. 2000, 39, 1221-1227

1918 https://webbook.nist.gov

2019 A. Lepoetre, S. Ognier, M. Zhang, J. Wengler, S. Al Ayoubi, C. Ollivier, L. Fensterbank, X. Duten, M. Tatoulian, Plasma Chem. Plasma Process, 2021, 41, 351-368. 